\title{
Crotalaria species in succession to soybean for the management of Pratylenchus brachyurus
}

\section{Thays Torquato Cruz $^{1 *}$ (D) Guilherme Lafourcarde Asmus ${ }^{2}$ (D) Rodrigo Arroyo Garcia ${ }^{2}$ (D)}

${ }^{1}$ Programa de Pós-graduação em Agronomia, Universidade Estadual de Mato Grosso do Sul (UEMS), 79200-000, Aquidauana, MS, Brasil. E-mail: thaystorquato@hotmail.com. "Corresponding author.

${ }^{2}$ Embrapa Agropecuária Oeste, Dourados, MS, Brasil.

ABSTRACT: Soybean is the main agricultural crop in the State of Mato Grosso do Sul, Brazil. It is primarily cultivated in a crop succession system, in wich soybean is grown in spring/summer, followed by corn or graminaceous pastures in autumn/winter as a second crop. Due to the intensive cultivation, new phytosanitary problems have arisen, among them the root-lesion nematode, Pratylenchus brachyurus, which besides causing damage to plant roots, can be important gateway for other soil pathogens. The recent occurrence of high nematode population densities has brought great concern due to the limited resistant soybean genotypes available. Besides, the use of nematicides only reduces nematodes populations temporarily. A viable alternative for the control of soil nematodes could be the use of Crotalaria spp. in succession or rotation with soybean. Crotalaria is immune or a bad host to the nematode, besides having high capacity of biological nitrogen fixation. Thus, the objective of the present research was to define the best way of insertion of this legume as a second crop in soybean production systems to reduce the population density of the rootlesion nematode. Two experiments were carried out: one in the field, in an infested area, and other in a greenhouse. In both experiments, the treatments were: 1) Zea mays, 2) Brachiaria brizantha cv. Xaraés,, 3) Z. mays + Crotalaria spectabilis, 4) Z. mays + C. ochroleuca, 5) B. brizantha cv. Xaraés + C. spectabilis, 6) B. brizantha cv. Xaraés + C. ochroleuca, 7) C. spectabilis, and 8) C. ochroleuca. The effect of the treatments was evaluated by estimating the number of nematodes in the roots of autumn/winter crops, as well as in the roots of the soybean cultivated in the sequence. The cultivation of both Crotalaria species provided suppression of the nematode population. However, when intercropped with corn or Xaraés palisade grass, the suppressive effect of Crotalaria was supplanted by corn and Xaraés palisadegrass susceptibility to the root-lesion nematode. Key words: root-lesion nematode, Glycine max, Crotalaria spectabilis, Crotalaria ochroleuca, Zea mays, Brachiaria brizantha.

Espécies de Crotalaria em sucessão à soja para o manejo de Pratylenchus brachyurus

RESUMO: A soja é a principal cultura agrícola explorada no Estado do Mato Grosso do Sul, cultivada prioritariamente no sistema de sucessão com milho safrinha. Com expansão da cultura, novos problemas fitossanitários surgiram, como o nematoide das lesões radiculares, Pratylenchus brachyurus. A ocorrência recente de altas densidades populacionais do nematoide trouxe preocupação pela limitada quantidade de genótipos de soja resistentes e o uso de nematicidas reduzir temporariamente a população. Uma alternativa viável para controle seria o uso de crotalária em sucessão ou rotação com a soja, pois esta é má hospedeira ou imune a nematoides. Assim, o objetivo do presente trabalho foi definir a melhor forma de inserção dessa leguminosa em sucessão com soja para redução da densidade populacional do Pratylenchus brachyurus. O trabalho consistiu de dois experimentos: à campo, em uma área infestada, e em casa de vegetação. Os tratamentos utilizados em ambos experimentos foram: 1) Zea mays, 2) Brachiaria brizantha cv. Xaraés, 3) Z. mays + Crotalaria spectabilis, 4) Z. mays + C. ochroleuca, 5) Xaraés + C. spectabilis, 6) Xaraés + C. ochroleuca, 7) C. spectabilis, 8) C. ochroleuca. O efeito dos tratamentos sobre densidade populacional do nematoide foi avaliado por: estimativa do número de nematoides nas raizes; cálculo da variação da população durante todo o experimento; fator de reprodução e; características fitotécnicas. O cultivo das espécies de Crotalaria, sem consorciação, proporcionaram supressão da população dos nematoides. Todavia o efeito supressor das crotalárias consorciadas foi suplantado pela suscetibilidade do milho e Xaraés ao Pratylenchus brachyurus.

Palavras-chave: nematoide das lesões radiculares, Glycine max, Crotalaria spectabilis, Crotalaria ochroleuca, Zea mays, Brachiaria brizantha.

\section{INTRODUCTION}

Soybean is the main agricultural crop in the State of Mato Grosso do Sul, Brazil. It is primarily cultivated in crop succession system, in which soybean is grown in spring/summer, followed by corn or graminaceous pastures in autumn/ winter as a second crop. Due to the intensive crop cultivation, new phytosanitary problems have arisen, among them the root-lesion nematode, 
which besides damaging plant roots, can be important gateway for other soil pathogens (GRIGOLLI, 2015; VEDOVETO et al., 2013).

The root-lesion nematode, Pratylenchus brachyurus Godfrey, is one of the most widespread phytonematodes in the soybean production areas of the Brazilian Savanna ("Cerrado"), causing losses of up to $30 \%$ in productivity. Damage to the root system occurs in the parenchyma region, due to the action of the toxins released during the movement and feeding of the phytonematodes (VEDOVETO et al., 2013).

Symptoms vary depending on the crop species, and are characterized by rot and necrosis of the root system due to the entry of bacteria and fungi. Generally, the parasitized roots are less bulky and developed, with partial or total darkening of the tissues. Plant shoots can show chlorosis and wilting in times of drought. It is not unusual to occur defoliation in times of drought and decrease in productivity (AGRIOS, 2005; ALVES et al, 2011; BARBOSA et al., 2013; BURIN, 2016; FERRAZ, 2006; TIHOHOD, 1993). The symptoms are nonspecific, and can easily go unnoticed or confused with other diseases, nutritional deficiency or water stress (INOMOTO et al., 2001).

Among the factors that contribute to the increase of the population density of $P$. brachyurus in the soil are: monoculture of susceptible crops, soil degradation with loss of organic matter and elimination of organisms that control nematodes (INOMOTO et al., 2001).

Compared to the conventional one, the notillage system can favor the survival of $P$. brachyurus, because the roots are less mecanically damaged and sun exposed, and there is higher availability of food for the nematode, since several cover crops can be host of the nematode.

Pratylenchus brachyurus management is not an easy task due to the difficulty of obtaining resistant soybean cultivars and the marked polyphagia, which limits the use of resistant or non-host plants in infested areas (ALVES et al., 2011). Besides, most crops indicated for crop rotation offer no economic return, so farmers choose to maintain the soybeancorn system. (SANTANA-GOMES et al.., 2014).

One option is the cultivation of antagonistic or non-host plants after soybean, as they may promote the reduction of the nematode population density. In this context, some species of Crotalaria could be introduced into soybean production systems, as a second crop, since they have already been properly characterized as resistant or immune to the nematode. Several Crotalaria species drastically reduces the population density of the nematode, which is attracted by root exudates and penetrates the roots, but do not complete its cycle, and hence prevent its reproduction (GOULART et al., 2013).

The objective of this research was to evaluate the effect of two Crotalaria species (C. spectabilis Roth and C. ochroleuca G. Don.) succeeded by soybean, either as single crops or intercropped with corn (Zea mays L.) or Xaraés palissadegrass (Brachiaria brizantha Hochstetter ex A Rich cv. Xaraés) on population density of the rootlesion nematode, P. brachyurus.

\section{MATERIALS AND METHODS}

Two similar experiments were carried out from March 2018 until February 2019; one in the field and another in the greenhouse. Eight treatments (crops or crop arrangement in succession to soybeans, in autumn/winter) were evaluated: 1) Corn Hybrid Ag8780 VTPro3, 2) Xaraés palissadegrass, 3) Corn + C. spectabilis, 4) Corn + C. ochroleuca, 5) Xaraés palissadegrass $+C$. spectabilis, 6) Xaraés palissadegrass $+C$. ochroleuca, 7) C. spectabilis, and 8) C. ochroleuca, succeeded by soybean sowed in the following spring.

The chemical and granulometric characteristic of the soil is presented in table 1.

\section{Field experiment}

The autumn/winter crops were sown on 03/07/2018, after soybean cultivar MSoy 6410 IPRO harvesting, in a naturally root-lesion nematode infested area, with an initial population of 130 nematodes/ 200 cc of soil, at Novo Horizonte Farm, in the country of Navirai, southwest of Mato Grosso do Sul, Brazil (22 $55^{\prime} 54^{\prime}$ 'S, $\left.54^{\circ} 20^{\prime} 27^{\prime \prime} \mathrm{W}\right)$. The prevailing climate is characterized by rainy summer and dry winter.

\section{Experimental design and seeding}

The experiment was performed in a randomized blocks design with four replicates. Each treatment was established in a 6 meters wide and 25 meters long field plot. For sowing the autumn/winter treatments it was used a sowing machine SHM1517, with a spacing of $45 \mathrm{~cm}$ between planting lines. In treatments with intercropping species, it was used an additional seed-box in the sowing machine, resulting in a spacing of $22.5 \mathrm{~cm}$ between the planting lines.

The sowing density of Xaraés palisade grass was, $3.5 \mathrm{~kg} \mathrm{ha}^{-1}$ or $2.1 \mathrm{~kg} \mathrm{ha}^{-1}$ of viable pure seeds, respectively, as a single crop or intercropped with Crotalaria species. Seed densities of Crotalaria 
Table 1 - Chemical and granulometric characteristics of the field soil used in the experiments.

\begin{tabular}{lccccccccccccccccc}
\hline Depth & $\mathrm{pH}$ & $\mathrm{Al}^{3+}$ & $\mathrm{Ca}^{2+}$ & $\mathrm{Mg}^{2+}$ & $\mathrm{H}^{+}+\mathrm{Al}^{3+}$ & $\mathrm{K}^{+}$ & $\mathrm{P}(\mathrm{Mehlich}-1)$ & $\mathrm{OM}$ & Sand & Silt & $\mathrm{Clay}$ \\
\hline$(\mathrm{cm})$ & $(1: 2.5)$ & $\left(\mathrm{cmolc} \mathrm{dm}^{-3}\right)$ & $\left(\mathrm{cmolc} \mathrm{dm}^{-3}\right)$ & $\left(\mathrm{cmolc} \mathrm{dm}^{-3}\right)$ & $\left(\mathrm{cmolc} \mathrm{dm}^{-3}\right)$ & $\left(\mathrm{cmolc} \mathrm{dm}^{-3}\right)$ & $\left(\mathrm{mg} \mathrm{dm}^{-3}\right)$ & $\left(\mathrm{g} \mathrm{Kg}^{-1}\right)$ & $\mathrm{g} \mathrm{Kg}^{-1}$ & $\mathrm{~g} \mathrm{Kg}^{-1} \mathrm{~g} \mathrm{Kg}^{-1}$ \\
$0-10$ & 5.74 & 0.10 & 1.64 & 0.51 & 3.09 & 0.07 & 10.47 & 12.82 & 712.68 & 66.66 & 220.66 \\
$10-20$ & 5.79 & 0.00 & 1.48 & 0.59 & 2.61 & 0.06 & 4.22 & 12.33 & 696.01 & 66.66 & 237.32 \\
$20-40$ & 5.43 & 0.20 & 1.20 & 0.49 & 2.99 & 0.04 & 2.01 & 10.22 & 646.01 & 50.00 & 303.95 \\
\hline
\end{tabular}

spectabilis and C. ochroleuca were, respectively, 8 and $15 \mathrm{~kg} \mathrm{ha}^{-1}$ of viable pure seeds when single, and $60 \%$ less when intercropped. Final population of corn was about 60,000 plants $\mathrm{ha}^{-1}$. All treatments were conducted under no-tillage system.

\section{Plant management and nematode population ratings}

Based on soil analyzes, fertilization was only applied in treatments that had corn, in rates of $200 \mathrm{~kg} \mathrm{ha}^{-1}$ of NPK 10-10-15 in furrow, and $120 \mathrm{~kg}$ $\mathrm{ha}^{-1}$ of 20-02-20 in coverage. The soybean, either preceding or after the autumn/winter treatments, was fertilized with $300 \mathrm{~kg} \mathrm{ha}^{-1}$ of 2-20-20.

Initial (before treatments establishment) and final (after soybean harvesting) soil populations of $P$. brachyurus were evaluated. Twelve soil cores of $2.5 \times 20 \mathrm{~cm}$ were taken in a random scheme from each field plot as to have a compost sample. Nematodes were extracted from soil samples by gravity sieving followed by sucrose centrifugation, following the methodology of JENKINS (1964).

The nematode population in the roots was estimated three times: P1) 77 days after planting the treatments $(05 / 23 / 2018)$; P2) 60 days after emergence of second cycle soybean (01/09/2019); and P3) in the soybean harvesting (02/18/2019). Ten root subsamples were collected from the central lines of each plot, which, after being homogenized, were packed in plastic bags, labeled and packed in a thermal box to be sent to the laboratory.

Once in the laboratory, the roots were carefully washed in tap water to remove adhered soil. After washing, the roots were placed on absorbent paper for 20 minutes, for drying and subsequent weighing. For nematode extraction, roots were cut into 1 to $2 \mathrm{~cm}$ sections and processed by the blender grinding method with addition of $0.5 \%$ sodium hypochlorite, sieving (200 and 400 mesh sieves) and subsequent centrifugal clarification (COOLEN \& D'HERDE, 1972).

After extraction, nematodes were inactivated in a water bath at $55^{\circ} \mathrm{C}$ for five minutes and fixed in formalin (2\%) until being quantified. For counting, the aqueous nematode suspension was adjusted to the volume of $10 \mathrm{~mL}$, of which 1 $\mathrm{mL}$ was poured into Peters' slide for counting eggs and vermiforms under binocular optical microscope $(100 \mathrm{x})$, and the total numbers of root-lesion nematodes/gram of roots were estimated.

\section{Harvesting and productivity estimation}

At the end of the soybean cycle that succeeded the autumn/winter treatments, grain harvesting was performed. Three $5-\mathrm{m}$ sub-samples were collected manually in each plot. After mechanically tracing the samples, the grains were weighed and submitted for moisture determination. Productivity was adjusted to $13 \%$ water content.

\section{Greenhouse experiment}

The greenhouse experiment was conducted at Embrapa Agropecuária Oeste, in Dourados, State of Mato Grosso do Sul, from 03/28/2018 to $02 / 21 / 2019$, using soil collected from the field experiment site. Treatments were the same as that of the field experiment: the sequence soybean/autumnwinter crops/soybean. However, the soybean cultivar was BMX Potência. The experiment was performed in a randomized blocks design with eight replicates. Each plot was a 2,5 L clay pot containing naturally infested soil. During the experiment the temperature ranged from 20 to $32{ }^{\circ} \mathrm{C}$.

\section{Plant management and nematode extraction}

First-cycle soybean was sown in naturally infested soil in 03/28/2018 and maintained in greenhouse. Eighty days after sowing the shoots were cut off and the roots were carefully taken from the soil for nematode extraction. Then, the soil and remaining roots were replaced to the pots and three seeds of each autumn/winter crop were sown. After emergence, the plantlets were tinned to one/pot. For 
treatments with single species, plantlets were tinned to two/pot. Ninety days later, the shoots of all plants were cut off and the roots were taken for nematode extraction. The remaining soil and roots were replaced again to the pots, and second-cycle soybean was sown 10/04/2018 as to have one soybean plant/ pot. Soybean plants were harvested in Feb. $21^{\text {st }} 2019$.

The pots received at least two irrigations daily, in order to keep soil humidity close to the field capacity. Fertilization was always done before sowing, using two grams of NPK (04-20-20), directly on the scarified soil of each pot. Thrips, whitefly and mites were kept under control by weekly sprays of a $0,2 \%$ neem oil.

Root nematode population was estimated at three times: P1) about 80 days after sowing first-cycle soybeans (06/18/2018); P2) 97 days after the installation of the autumn/winter treatments (09/25/2018) and P3) at harvesting of second-cycle soybean (02/21/2019).

For treatments involving consortia, nematodes were extracted from the roots of each species separately. However, for data analysis the average of the two species was considered.

\section{Nematological and vegetative parameters}

For the evaluation of the effect of the treatments on the population density of the nematode, it was considered the number of nematodes. $\mathrm{g}^{-1}$ of root, using the same methodology previously described in field experiment. At the end of the experiment, the following phytotechnical variables were evaluated:

Plant height: A millimeter ruler was used to measure the height of the plants, obtaining the distance from the base to the apex of the plants.

Shoot dry mass: The stems were cut about $0.5 \mathrm{~cm}$ above ground level and the shoots were packed in paper bags for air drying at $60{ }^{\circ} \mathrm{C}$, until the dry mass reached a constant value.

Fresh mass of the roots: After the separation of the aerial part, roots were removed from the pots and rinsed in running water to remove the adhered soil. Roots were air dried on absorbent paper for about 20 minutes to remove excess of water, and weighed individually.

Yield: The numbers of pods per plant, beans per pod and the grain weight after drying at $13 \%$ moisture were assigned. Data were submitted to analysis of variance (ANOVA, $\mathrm{p}<0.05$ ), and media compared by Tukey test at $5 \%$ probability.

\section{RESULTS}

In both experiments the nematode population density did not evolve adequately, remaining relatively low, but high enough to allow evaluations of the efficiency of the treatments.

\section{Field experiment}

The number of nematodes. $\mathrm{g}^{-1}$ of roots (NGR) varied among treatments. At 60 days after planting autumn/winter crops $(05 / 23 / 18)$, NGR in treatments with $C$. spectabilis and $C$. ochroleuca, either as single crops or intercropped with corn or palisade grass, was significantly lower than that observed in single corn. Higher counting of NGR were observed in corn and palisade grass (16.7 and 11.5, respectively). Counting in C. spectabilis and $C$. ochroleuca as single crops remained low in soybean roots until the end of the season (01/09/2019 and 02/18/2019) Conversely, high populations of $P$. brachyurus were observed in roots of soybean cultivated after palisade grass $(\mathrm{NGR}=66,5)$. Despite of the evaluation time, palisade grass as single crop didn't differ of palisade grass intercropped with $C$. spectabilis or C. ochroleuca. NGR in corn intercropped with C. spectabilis or C. ochroleuca was lower than in corn as a single crop in the P1. However, this effect didn't last through P2 and P3 (Table 2).

As far as the variation of the NGR during the experiment (RF) is concerned, palisade grass was the only treatment that differed from both species of Crotalaria, that didn't differ from all other treatments. (Table 3).

Yield of soybeans cultivated after the offseason treatments (autumn / winter) are presented in table 4. Soybean yield after palisade grass, either single or intercropped with the two Crotalaria species, was significantly higher from that after corn. There was no difference in productivity of soybean after corn single or intercropped with $C$. spectabilis or C. ochroleuca. Although, Xaraés palisade grass did not suppress the root lesion nematode population, it contributed to increase soybean yield.

\section{Greenhouse experiment}

The nematode population in soybean roots (NGR) before stablishing the off-season treatments (P1) showed to be uniform with no significant differences (Table 5). Ninety days after planting the off-season crops (P2), NGR was low in C. spectabilis and $C$. ochroleuca roots, but didn't differ statistically from NGR in corn or palisade grass. Highest value of NGR was observed in corn $+C$. ochroleuca roots. Similarly to the results obtained in the field, low populations of $P$. brachyurus were observed in the roots of soybean that succeeded the treatments with $C$. spectabilils $(\mathrm{NGR}=8.9)$ and $C$. ochroleuca $(\mathrm{NGR}=3.9)$ as single crops and the highest NGR 
Table 2 - Number of nematodes Pratylenchus brachyurus per gram of roots of the crops (treatments) used in autumn/winter and soybean sown in sequence.

\begin{tabular}{lccc}
\hline Treatments & $\mathrm{P} 1$ & $\mathrm{P} 2$ & $\mathrm{P} 3$ \\
\hline Corn & $16.7 \mathrm{a}$ & $8.2 \mathrm{~b}$ & $24.0 \mathrm{ab}$ \\
B. brizantha cv. Xaraés & $11.5 \mathrm{ab}$ & $54.0 \mathrm{a}$ & $66.5 \mathrm{a}$ \\
Xaraés + C. spectabilis & $5.0 \mathrm{bc}$ & $24.2 \mathrm{ab}$ & $41.0 \mathrm{ab}$ \\
Xaraés + C. ochroleuca & $3.7 \mathrm{bc}$ & $28.5 \mathrm{ab}$ & $36.2 \mathrm{ab}$ \\
Corn+ C. spectabilis & $3.7 \mathrm{bc}$ & $18.0 \mathrm{ab}$ & $34.2 \mathrm{ab}$ \\
Corn + C. ochroleuca & $3.0 \mathrm{bc}$ & $3.0 \mathrm{~b}$ & $16.0 \mathrm{ab}$ \\
C. spectabilis & $2.5 \mathrm{c}$ & $2.5 \mathrm{~b}$ & \\
C. ochroleuca & $4.2 \mathrm{bc}$ & $8.0 \mathrm{~b}$ & \\
CV $(\%)$ & 57.78 & 84.86 & 76.65 \\
\hline
\end{tabular}

Means followed by different letters in the column differ significantly by the Tukey test $\mathrm{P}(\mathrm{P}<.05)$

P1: 05/23/2018, 80 days after planting of autumn/winter crops.

P2: 01/09/2019, 97 days after the emergence of soybeans.

P3: 02/18/2019, at the time of the soybean harvest.

was observed in soybean roots after palisade grass (40.7) which didn't differ from palisade grass $+C$. spectabilis (22.2) and palisade grass + C. ochroleuca (27.0). The NGR after corn as single crop (23.4) was similar to corn $+C$. spectabilis $(26.0)$ or corn $+C$. ochroleuca (24.6). There were no significant effects of the treatments on any of the variables related to soybean yield (Table 6).

\section{DISCUSSION}

The results obtained in this research confirmed the efficiency of $C$. spectabilis and $C$. ochroleuca in reducing the populational density of $P$. brachyurus. Previous researches have shown that both species are resistant or immune to the nematode, with a reproduction factor equal to or close to zero (VEDOVETO et al., 2013; INOMOTO et al., 2006; COSTA et al., 2014).

The mechanisms of action of these plant species are primarily based on the ability to act as a trap plants, which allowed nematodes to penetrate the roots but do not allow subsequent development, and the production of monocrotaline, a secondary metabolite with nematicidal properties. Besides, they can also act as soil-enhancing plants (VEDOVETO et

Table 3 - Reproduction factor $(\mathrm{RF}=\mathrm{P} 3$ / P1) of Pratylenchus brachyurus in soybean roots, after autumn/winter treatments.

\begin{tabular}{lc}
\hline Treatments & $\mathrm{RF}$ \\
\hline Corn & $5.6 \mathrm{~b}$ \\
B. brizantha cv. Xaraés & $25.6 \mathrm{a}$ \\
\hline Xaraés + C. spectabilis & $12.9 \mathrm{~b}$ \\
Xaraés+C. ochroleuca & $1.7 \mathrm{ab}$ \\
Corn+C. spectabilis & $15.2 \mathrm{~b}$ \\
Corn+C. ochroleuca & $4.6 \mathrm{ab}$ \\
C. spectabilis & $0.6 \mathrm{~b}$ \\
C. ochroleuca & $0.5 \mathrm{~b}$ \\
CV $(\%)$ & 98.5 \\
\hline
\end{tabular}

Means followed by different letters in the column differ significantly by the Tukey test $(\mathrm{P}<0.05)$.

P1: 05/23/2018, 75 days after planting of autumn/winter crops.

P3: 02/18/2019, at the time of the soybean harvest. 
Table 4 - Productivity of soybean sown after different crops (treatments) of autumn/winter.

\begin{tabular}{lc}
\hline Treatments & Produtivity $\left(\mathrm{Kg} . \mathrm{ha}^{-1}\right)$ \\
\hline Corn & $2603.5 \mathrm{c}$ \\
B. brizantha cv. Xaraés & $3380.9 \mathrm{ab}$ \\
Xaraés+C.spectabilis & $3583.5 \mathrm{a}$ \\
Xaraés+C.ochroleuca & $3545.3 \mathrm{a}$ \\
Corn+C.spectabilis & $2865.2 \mathrm{bc}$ \\
Corn+C.ochroleuca & $3063.7 \mathrm{abc}$ \\
C. spectabilis & $3565.6 \mathrm{a}$ \\
C. ochroleuca & $3017.1 \mathrm{abc}$ \\
CV $(\%)$ & 8.9
\end{tabular}

Values followed by different letters in the column differ significantly by the Tukey test.

al., 2013). However, their introduction into a soybean production system, as off-season or second crops, is limited by economic reasons. By far, they cannot give the same income that is obtained with corn.

Corn is the most used crop in succession with soybean, but it is a good host of P. brachyurus and more susceptible then forage grasses, as verified by DIAS-ARIEIRA et al. (2009). Our results showed that inter-cropping $C$. spectabilis or $C$. ochrolleuca with corn did not help to lower the nematode population as well as did not increase soybean yield. The susceptibility of corn to root-lesion nematode probably overcome the benefits of $C$. spectablis or C. ochroleuca planted as intercropping crops. In a similar field experiment carried out in naturally nematode-infested soil (AMORIM et al., 2019), the population density of $P$. brachyurus in soybean roots cultivated after corn was 1,012.2 nematodes. When soybean was planted after $C$. ochroleuca, the population density in the roots was 327.2 nematodes. Although, there are few data in the literature on the reaction of the Xaraés palisade grass to $P$. brachyurus, it is clear from the results obtained in our research that this grass is susceptible to the nematode. Other varieties of Brachiaria brizanta, such as B4, Piatã and Paiaguás, have also shown to be susceptible to P. brachyurus (QUEIRÓZ et al, 2014). Similarly to that observed when intercropping with corn, the effects of resistance of $C$. spectabilis and $C$. ochroleuca where supplanted

Table 5 - Number of nematodes Pratylenchus brachyurus nematodes. $\mathrm{g}^{-1}$ of roots of crops (treatments) used in autumn/winter and soybeans planted in sequence in the greenhouse experiment.

\begin{tabular}{lccc}
\hline Treatments & P1 & P2 & P3 \\
\hline Corn & $81.7^{\mathrm{ns}}$ & $14.5 \mathrm{abcd}$ & $23.4 \mathrm{abc}$ \\
B. brizantha cv. Xaraés & $87.7^{\mathrm{ns}}$ & $3.3 \mathrm{~cd}$ & $40.7 \mathrm{a}$ \\
Corn+C. spectabilis & $65.6^{\mathrm{ns}}$ & $17.7 \mathrm{abcd}$ & $26.0 \mathrm{ab}$ \\
Corn+C. ochroleuca & $58.5^{\mathrm{ns}}$ & $26.6 \mathrm{ab}$ & $24.6 \mathrm{ab}$ \\
Xaraés+C. spectabilis & $75.7^{\mathrm{ns}}$ & $7.2 \mathrm{~cd}$ & $22.2 \mathrm{abc}$ \\
Xaraés+C. ochroleuca & $95.5^{\mathrm{ns}}$ & $12.8 \mathrm{bcd}$ & $27.0 \mathrm{ab}$ \\
C. spectabilis & $84.6^{\mathrm{ns}}$ & $6.2 \mathrm{~cd}$ & $8.9 \mathrm{bc}$ \\
C. ochroleuca & $98.2^{\mathrm{ns}}$ & $1.1 \mathrm{~d}$ & $3.9 \mathrm{c}$ \\
CV $(\%)$ & 38.9 & 69.1 & 49.2 \\
\hline
\end{tabular}

Values followed by different letters in the column differ significantly by the Tukey test.

${ }^{\mathrm{ns}}$ : Not significant by the Tukey test, at $5 \%$ significance.

P1: 06/18/2018, at 50 days after sowing of the soybean that preceded the treatments.

P2: 09/25/2018, at 90 days after establishment of treatments (autumn / winter crops).

P3: $02 / 21 / 2019$, at the time of harvesting the soybean cultivated in sequence to the treatments. 
Table 6 - Plant height (PH), dry shoot mass (DSM), fresh mass of the root system (FMRS), number of pods per plant, number of grains / pod (No. of b / P) and mass of 100 soya beans cultivated after autumn / winter crops (treatments) in greenhouse experiment.

\begin{tabular}{|c|c|c|c|c|c|c|}
\hline Treatments & $\mathrm{PH}(\mathrm{cm})$ & $\operatorname{DSM}(\mathrm{g})$ & FMRS (g) & $\mathrm{N}^{\mathrm{o}}$ of pods & $\mathrm{N}^{\mathrm{o}}$ of $\mathrm{b} / \mathrm{P}$ & Mass of 100 soya beans $(\mathrm{g})$ \\
\hline Corn & $64.61^{\mathrm{ns}}$ & $38.86^{\mathrm{ns}}$ & $37.70^{\mathrm{ns}}$ & $22.12^{\mathrm{ns}}$ & $2.4^{\mathrm{ns}}$ & $16.42^{\mathrm{ns}}$ \\
\hline B. brizantha cv. Xaraés & $61.41^{\mathrm{ns}}$ & $42.37^{\mathrm{ns}}$ & $38.38^{\mathrm{ns}}$ & $25.00^{\mathrm{ns}}$ & $2.6^{\mathrm{ns}}$ & $14.57^{\mathrm{ns}}$ \\
\hline Corn $+C$. spectabilis & $69.24^{\mathrm{ns}}$ & $45.79^{\mathrm{ns}}$ & $54.07^{\mathrm{ns}}$ & $25.12^{\mathrm{ns}}$ & $2.6^{\mathrm{ns}}$ & $13.15^{\mathrm{ns}}$ \\
\hline Corn + C. ochroleuca & $63.08^{\mathrm{ns}}$ & $40.43^{\mathrm{ns}}$ & $37.88^{\mathrm{ns}}$ & $24.37^{\mathrm{ns}}$ & $2.6^{\mathrm{ns}}$ & $14.41^{\mathrm{ns}}$ \\
\hline Xaraés $+C$. spectabilis & $64.85^{\mathrm{ns}}$ & $42.92^{\mathrm{ns}}$ & $48.24^{\mathrm{ns}}$ & $26.62^{\mathrm{ns}}$ & $2.4^{\mathrm{ns}}$ & $15.32^{\mathrm{ns}}$ \\
\hline Xaraés $+C$. ochroleuca & $63.69^{\mathrm{ns}}$ & $39.19^{\text {ns }}$ & $41.42^{\mathrm{ns}}$ & $24.50^{\mathrm{ns}}$ & $2.5^{\mathrm{ns}}$ & $15.54^{\mathrm{ns}}$ \\
\hline C. spectabilis & $62.31^{\mathrm{ns}}$ & $46.99^{\mathrm{ns}}$ & $38.83^{\text {ns }}$ & $25.88^{\mathrm{ns}}$ & $2.5^{\mathrm{ns}}$ & $15.69^{\mathrm{ns}}$ \\
\hline C. ochroleuca & $64.36^{\mathrm{ns}}$ & $48.48^{\mathrm{ns}}$ & $42.16^{\mathrm{ns}}$ & $27.75^{\mathrm{ns}}$ & $2.4^{\mathrm{ns}}$ & $16.07^{\mathrm{ns}}$ \\
\hline $\mathrm{CV}(\%)$ & 11.02 & 15.01 & 33.89 & 17.33 & 9.22 & 9.21 \\
\hline
\end{tabular}

${ }^{\mathrm{ns}}$ : Not significant by the Tukey test, at $5 \%$ significance.

by the high susceptibility of Xaraés palisadegrass to corn, However, even being susceptible to the nematode, palisade grass promoted high soybean yields. UEBEL et al., (2013) evaluated the effect of Brachiaria species on the root lesion nematode and also reported Xaraés palisade grass was susceptible to the pathogen, in relation to the other grasses and Crotalaria spectabilis.

The differences in soybean yields observed in the field experiment cannot be attributed solely to the effect of treatments on $P$. brachyurus. That comes clear when observing the high productivity obtained after growing palisade grass. The high amount of straw and vigorous roots produced by palisade grass probably played an important role in improving soybean yield, either with or without $C$. spectabilis or C. ochroleuca as intercropping crops. AMORIM (2019) also reported that $C$. spectabilis and $C$. ochroleuca were effective in reducing $P$. brachyurus population but did not improve soybean yield due to the low supply of straw to the soil. In a greenhouse trial, Mainardi \& Asmus (2015) observed that $P$. brachyurus is a week pathogen, and did not cause damage to soybean when soil conditions are favorable to the crop. The same was observed by DEBIASI et al. (2016) in soybean crops. So, crops that somehow improve soil quality, like Xaraés palisade grass, could overcome damage caused by the root-lesion nematode and improve soybean productivity.

\section{CONCLUSION}

Based on our results, we conclude that Crotalaria spectabilis and C. ochroleuca grown in succession to soybean as off-season or second crop contribute to reduce the population density of the root-lesion nematode (Pratylenchus brachyurus). When intercropped with corn or Xaraés palisade grass, C. spectabilis and C. ochroleuca did not reduce the population of root-lesion nematode. Even not controlling the root-lesion nematode Xaraés palisade grass improved the productivity of soybean grown in root-lesion nematode infested soil.

\section{ACKNOWLEDGEMENTS}

The authors would like to thank Embrapa Agropecuária Oeste, located in Dourados-MS, and Fazenda Novo Horizonte, located in Naviraí-MS, for allowing the use of its facilities and technical support. This research was funded by Fundação de Apoio ao Desenvolvimento do Ensino, Ciência e Tecnologia do Estado de Mato Grosso do Sul (FUNDECT) and Coordenação de Aperfeiçoamento de Pessoal de Nível Superior (CAPES).

\section{DECLARATION OF CONFLICT OF INTERESTS}

The authors declare no conflict of interest. The founding sponsors had no role in the design of the study; in the collection, analyses, or interpretation of data; in the writing of the manuscript, and in the decision to publish the results.

\section{AUTHORS' CONTRIBUTIONS}

All authors contributed equally for the conception and writing of the manuscript. All authors critically revised the manuscript and approved of the final version.

\section{REFERENCES}

AGRIOS, G. N. Plant diseases caused by nematodes. Plant Pathology. 5 ed. Academic Press, 2005. 952p.

Ciência Rural, v.50, n.7, 2020. 
ALVES, T. C. U. et al. Host status of soybean cultivars to lesion nematode Pratylenchus brachyurus. Revista Biodiversidade. v.10, n.1, 2011. Available from: $<$ http://periodicoscientificos.ufmt br/ojs/index.php/biodiversidade/article/view/538/459>. Accessed: May, 01, 2019

AMORIM, D. J. et al. Management alternatives for Pratylenchus brachyurus in soybean crop. Journal of Agricultural Science, v.11, n.4, p.333-340, 2019. Available from: <http://www.ccsenet. org/journal/index.php/jas/article/view/0/38740>. Accessed: May, 01, 2019. doi: 10.5539/jas.v11n4p333.

BARBOSA, B. F. F. et al. Aggressiveness of Pratylenchus brachyurus to the sugarcane, compared with key nematode $\boldsymbol{P}$. zeae. Nematropica, v.43, n.1, p.119-130, 2013. Available from: $<$ https:// journals.flvc.org/nematropica/article/view/82441>. Accessed: May, 01, 2019.

BURIN, P. C. Manejo de Pratylenchus sp. em áreas de integração lavoura-pecuária. Revista electrónica de Veterinaria, AndalucíaEspanha, v.17, n.8, 2016. Available from: <http://www.redalyc. org/articulo.oa?id=63647455001>. Accessed: May, 01, 2019. E-ISSN: 1695-7504.

COOLEN, W. A.; D'HERDE, C. J. A. Method for the quantitative extraction of nematodes from plant tissue. Ghent: State Nematology and Entomology Research Station, 77p. 1972.

COSTA, M. J. N. et al. Effect of soil organic matter content, cover crop and planting system on the control of Pratylenchus brachyurus in soybean. Summa Phytopathologica, Botucatu-SP, v.40, n.1, p.63-70, 2014. Available from: <http://dx.doi.org/10.1590/S010054052014000100009>. Accessed: May, 01, 2019. doi: 10.1590/ S0100-54052014000100009.

DEBIASI, H. et al. Cultural practices during the soybean off-season for the control of Pratylenchus brachyurus. Pesquisa Agropecuária Brasileira, v.51, n.10, p.1728-1728, 2016. Available from: $<\mathrm{http}: / /$ dx.doi.org/10.1590/s0100-204x2016001000003>. Accessed: May, 01, 2019. doi: 10.1590/s0100-20.4x2016001000003.

DIAS-ARIEIRA, C. R. et al. Reaction of forage grasses to Pratylenchus brachyurus. Nematologia Brasileira, Piracicaba-SP, v.33, n.1, p.90-93, 2009. Available from: $<$ https://www.researchgate. net/publication/242682174_Reacao_de_Gramineas_Forrageiras_a Pratylenchus brachyurus>. Accessed: May, 01, 2019.

FERRAZ, L. C. C. B. O nematoide Pratylenchus brachyurus e a soja sob plantio direto. Revista Plantio Direto, Passo Fundo, 2006, p.23-27. Available from: <https:/www.researchgate.net/ publication/286368746>. Accessed: May, 01, 2019.

GOULART, M. M. P. et al. Evaluation of the effect $\mathrm{ff}$ different populations of Pratylenchus brachyurus in soybean crop. Global Science and Technology. Rio Verde- GO, v.6, n.2, p.08-14,
2013. Available from: <http://dx.doi.org/10.14688/1984-3801. v06n02a01>. Accessed: May, 01, 2019. doi: 10.14688/1984-3801. V06N02A01.

GRIGOLLI, J. F. J. Manejo de nematoides na cultura da soja. In: LORENÇÃO, A. L. F. Tecnologia e Produção: Soja 2014/2015. 1 ed. Maracaju-MS: Fundação MS, p.125-133, 2015.

INOMOTO, M. M. et al. Effect of population densities of Pratylenchus brachyurus on the growth of cotton plants. Fitopatologia Brasileira. v.26, n.1, p.192-196. 2001. Available from: <http://dx.doi. org/10.1590/S0100-41582001000200013>. Accessed: May, 01, 2019. doi: 10.1590/S0100-41582001000200013.

INOMOTO, M. M et al. Host status of six green manures to Meloidogyne javanica and Pratylenchus brachurus. Nematologia Brasileira, Piracicaba-SP, v.30, n.1, p.39-44, 2006.

JENKINS, W. R. A rapid centrifugal-flotation technique for separating nematodes from soil. Plant Disease Reporter, v.48, n. $9,692 \mathrm{p}, 1964$

MAINARDI, J. T.; ASMUS, G.L. Damage and reproductive potential Pratylenchus brachyurus on five selected plant species. Revista de Agricultura Neotropical, CassilândiaMS, v.2, n.4, p.38-47, 2015. Available from: <https://doi. org/10.32404/rean.v2i4.683I>. Accessed: May, 01, 2019. doi: $10.32404 /$ rean.v2i4.683.

QUEIRÓZ, C. A et al. Reaction of accessions and cultivars of Brachiaria spp. and Panicum maximum to Pratylenchus brachyurus. Summa Phytopathologica, Botucatu-SP, v.40, n.3, p.226-230, 2014. Available from: <https://doi. org/10.1590/0100-5405/1899>. Accessed: May, 01, 2019. doi: $10.1590 / 0100-5405 / 1899$.

SANTANA-GOMES, S. M. et al. Crop succession in the control of Pratylenchus brachyurus in soybean. Nematropica, v.44, n.1, p.200-206, 2014. Available from: <https://journals.flvc.org/ nematropica/article/view/84285>. Accessed: May, 01, 2019.

TIHOHOD, D. Nematologia Agrícola Aplicada. 1ed. JaboticabalSP: FUNEP, 1993. 372p.

UEBEL, M. et al. Reação de cultivares de Brachiaria spp. a Pratylenchus brachyurus. Connection Line, v.10, n.1, p.122-128, 2013. Available from: <http://dx.doi. org/10.18312\%2F1980-7341.n10.2013.541>. Accessed: May, 01, 2019. doi: 10.18312/2F1980-7341.

VEDOVETO, M. V. V. et al. Green manure in the management of Pratylenchus brachyurus in soybean. Nematropica, v.43, n.1, p.226-232, 2013. Available from: <https://journals.flvc.org/ nematropica/article/view/82711>. Accessed: May, 01, 2019. ISSN2220-5608/ISSN2220-5616. 